\author{
László Bartók
}

\title{
Climate Change \\ and the Hungarian Fiscal and Monetary Policy
}

\section{Summary}

In the last months of 2018, every weekend tens of thousands of people demonstrated on the streets in France. The main reason of the demonstrations was the rising petrol prices and its environmental tax that the government wanted to raise according to the 2014 law. The French example shows that in many cases the measures against the climate change can provoke a very deep resistance from a major part of the society; meanwhile the global climate change became a bigger and bigger danger for humanity. In the first part of my publication, I will shortly examine how the climate change became an important issue globally in the last 20 years; and how environmental pollution and the related climate change have become an important research subject in the economy and the answers the scholars gave for these challenges. In the second part I will show the toolkit the fiscal policy disposes to mitigate the climate change, and finally I will examine why and how the monetary policy and the financial system must be involved in the fight against climate change.

Journal of Economic Literature (JEL) codes: Q58, Q55, E52, E62

Keywords: climate change, fiscal policy, monetary policy, green finance

LÁszló Bartók PhD student, University of Szeged, Faculty of Economics and Business Administration Doctoral School (laszlo.bartok.1988@outlook.com). 


\section{László Bartók: Climate Change and the Hungarian Fiscal and Monetary Policy}

The Hungarian Fiscal Policy and Climate change

It was via the environment-related taxes that the Hungarian government, in accordance with the EU legislation, tried to regularize the negative environmental externalities in order to - directly or indirectly - decrease the effect of climate change. The European Commission's relevant country report (2019) included in the Environmental Implementation Review gives us a good insight into the importance of environment-related taxes in Hungary. The Commission examines the Hungarian environmental tax system in detail and establishes that "Hungary's revenues from environment-related taxes remain higher than the EU average. Environmental taxes are accounted for 2.53\% of GDP in 2017 (EU28 average: 2.4\%) and energy taxes for 1.91\% of GDP (Chart 1). In the same year, environmental tax revenues were $6.6 \%$ of the total revenues from taxes and social security contributions (EU average 5.97\%). However, according to the Commission, the consumption taxes remained relatively high (40.2\%, 6th in EU28), pointing out the limited potential of shifting taxes from labour to consumption and in particular to environmental ones, therefore the Commission has recommended that Hungary should modify its taxation system" (EC, 2019, p. 26).

Chart 1: Environmental tax revenues as a percentage of GDP (2017)

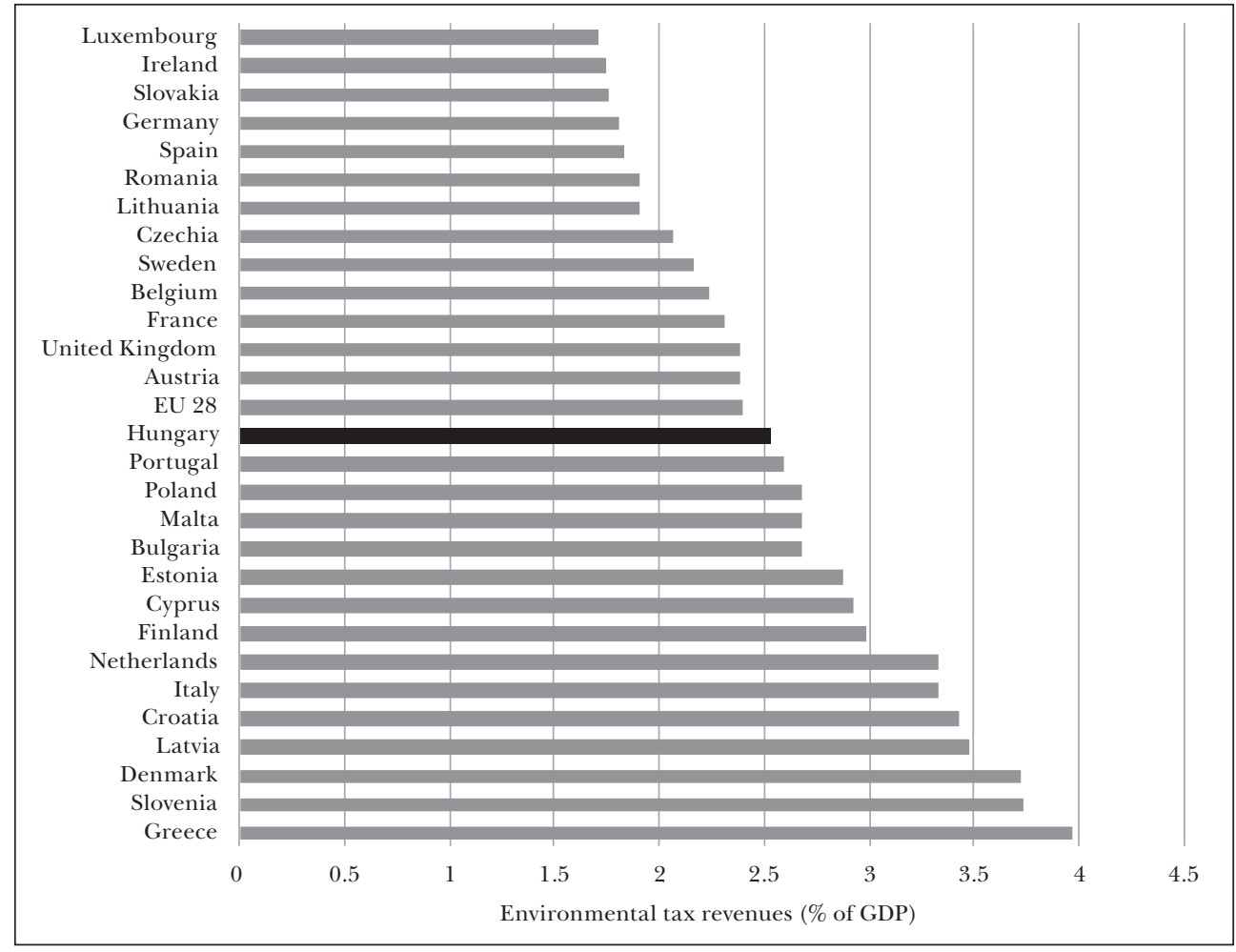

Source: Eurostat 
In 2009, Sipos (2009) distinguished 17 various environment-related fiscal policy tools, including taxes, tolls, fees and allowances. In addition to environmental pollution and environmental product fees (road tolls, travel cards, energy taxes and gas price subsidies for households), this list also includes taxes which have an indirect effect on climate change, like business taxes and construction taxes. Although most of these taxes, fees, tolls and allowances are still in force, some of them, like the tax break for biofuel, have already been abolished, meanwhile, new tools have also appeared in the past ten years. However, the collection and analysis of the current environmentrelated fiscal policy tools fall beyond the scope of this publication.

This paper discusses the fiscal policy tools suitable for encouraging the corporate sector to consider environmental aspects in investment decisions. One of the most essential tools is a tax credit for energy efficiency purposes in an investment. Taxpayers can reduce their annual corporate taxes (for the next five years) by a partial amount of the investment cost, if the investment meets the environmental objectives, and if the ultimate energy consumption of the company decreases as a result of the investment. The law endeavours to support small enterprises by enabling them to decrease their corporate taxes by $70 \%$, or $50 \%$ and $30 \%$ for the medium and big companies, respectively (National Tax and Customs Administration, 2018).

However, corresponding to environment-related taxation, bigger companies can also have another corporate tax allowance in the framework of the development tax credit. If a company makes a minimum of HUF 100 million independent environmental investment, it can claim a tax allowance in the year following the commissioning of the capital investment project (Veress and Bardócz, 2017).

In the field of households, in 2006 the Hungarian government approved a tax policy tool to support the sale of electric cars. The government grants a subsidy (in an amount of HUF 1.5 million) to customers who buy such eco-friendly vehicles. The sales price of the car is decreased by the amount of the subsidy. In addition to this support, customers are also relieved from paying the company car tax, the registration tax and the fee charged for the transfer of ownership.

\section{The National Bank of Hungary and climate Ghange}

In February 2019, the National Bank of Hungary (Magyar Nemzeti Bank, MNB) adopted its green policy programme which was, on the one hand, a response of the increasingly serious climate change, and on the other, the central bank realised the importance of green financing and the role of the monetary policy in this field. The purpose of MNB was to provide a far more powerful support to environmental sustainability than currently, through the financial products and services of the domestic system of financial intermediary. In accordance with its statutory mandate, through the Green Finance Programme MNB supports the stability of the financial intermediary system in order to ensure that the financial system promotes sustainable development in the economy and achievement of the government's economic policy objectives. 


\section{László Bartók: Climate Change and the Hungarian Fiscal and Monetary Policy}

Based on the National Energy and Climate Plan of the Hungarian Government, on international experiences, research and the priorities of the central bank, the three pillars of MNB's Green Finance Programme include the following:

1. Green Programme for the Hungarian Financial Sector

2. Social and International Relations

3. Eco-friendly Operation by the Central Bank

\section{Green Programme for the Hungarian Financial Sector}

The first pillar includes an ecological and a financial risk analysis. "For MNB, as the financial and monetary authority, one of the most important tasks and responsibilities is to identify the risks involved in climate change (and other ecological anomalies, a megatrend with widespread social and economic implications, for financial institutions and their customers" (National Bank of Hungary, 2009, p. 7). This factor is new within the scope of the financial monetary authority. Accordingly, the central bank and the actors of the financial system are required to observe, analyse and prepare forecasts for the long-term economic and financial effects of climate change.

The first pillar of MNB's Green Programme includes the mobilization and greening of financial services: shifting resources towards the "green" way, and contribution by the financial system to Hungary's sustainable ecological catch-up. MNB intends to encourage the issue of green financial products and sharing the best practices in this field, while also supporting incorporation of ecological and environmental aspects in classical credit products. In addition, MNB wishes to encourage banks and other providers of financial services (for example, insurance companies) to promote and spread green approaches.

Finally, in addition to preparing new green financial instruments, the actors of the financial market also need to change their operation using digital and other types of innovations which can help decrease the ecological footprint of the company. Pursuant to this act, they must set an example for the public and engage them in the combat against climate change. Therefore, MNB supports banks in incorporating ecological considerations in their operational processes (decrease in paper use, the digitalization of basic banking operation, and the creation of Green Bank Awards for the greenest bank of the year etc.)

\section{Social and International Relations}

Besides improving the financial system, the National Bank of Hungary tries to build a good social and international network as the second pillar of MNB's Green Finance Programme. Therefore, the monetary authority's objective is to create a good and close relationship with the relevant governmental, academic and social actors. According to MNB, the (financial) education of the next generation is one of the most important factors in building a healthy and effective financial system, thus the central 
bank extensively supports financial education and wants green finance to be the part of financial education at Hungarian universities.

Concerning international relationships, MNB joined the Central Banks and Supervisors Network for Greening the Financial System in January 2019.

\section{The eco-friendly operation of the National Bank of Hungary}

Finally, the National Bank of Hungary intends to set an example in green and environmental institutional operation. Therefore, as the third pillar of MNB's Green Financial Programme, it also wants to decrease its own ecological footprint.

\section{REFERENGES}

EC (2019): The Environmental Implementation Review 2019. Country Report Hungary. European Commission, Brussels, https://ec.europa.eu/environment/eir/pdf/report_hu_en.pdf.

Ministry of Finance (2016): Elektromos gépkocsi beszerzésének támogatása [Aid to the acquisition of electric cars]. Ministry of Finance, Budapest, www.kormany.hu/download/9/d8/21000/gzr-d-ö-2016_elektromos-gepkocsi-palyazat_mod.pdf.

National Tax and Customs Administration (2018): Az energiahatékonysági célokat szolgáló beruházás adókedvezménye [Tax benefits on CAPEX serving energy efficiency purposes]. NAV, Budapest, www.nav.gov.hu/ data/cms439929/Energiahatekonysagi_beruhazas_adokedvezmenye_tajekoztato_20180518.pdf.

Sipos, N. (2009): Az adók, díjak, járulékok externális hatásai környezetvédelmi szempontból [External impacts of taxes, charges and dues in an environmental perspective]. Gazdálkodás, Vol. 53, No. 5, pp. $456-459$.

The National Bank of Hungary (2019): Az MNB zöld programja [MNB's Green Programme]. MNB, Budapest, www.mnb.hu/letoltes/az-mnb-zold-programja.pdf.

Veress, J. and Bardócz, I. (2017): Fejlesztési adókedvezmény a társasági adóban [Development tax benefit in corporate tax]. Wolters Kluver, Budapest, https://ado.hu/ado/fejlesztesi-adokedvezmeny-a-tarsasagiadoban/. 